\title{
Individual olfactory fingerprints: from mapping odors in people-space to mapping people in odor-space
}

Lavi Secundo ${ }^{*}$ Kobi Snitz, Liron Pinchover, Dana Bar-Zvi, Noam Sobel

From 1st International Workshop on Odor Spaces

Hannover, Germany. 4-7 September 2013

Abstract not submitted for publication.

Published: 16 April 2014

doi:10.1186/2044-7248-3-S1-P17

Cite this article as: Secundo et al:: Individual olfactory fingerprints: from

mapping odors in people-space to mapping people in odor-space.

Flavour 2014 3(Suppl 1):P17.

Submit your next manuscript to BioMed Central and take full advantage of:

- Convenient online submission

- Thorough peer review

- No space constraints or color figure charges

- Immediate publication on acceptance

- Inclusion in PubMed, CAS, Scopus and Google Scholar

- Research which is freely available for redistribution 